\title{
IoT センサ・デバイスのための電池技術
}

\author{
秋 本 順 二**永 田

\section{1.はじめに}

IoT 社会の発展のためには, 様々な用途・使い方に適合 する多くの IoT センサ・デバイスの開発が必要となる. 例えば，ウェアラブル機器など，人間のからだに接触して 使用する機器の場合には，フレキシビリティと同時に高い 安全性が求められ, かつ使用方法として, 日常生活に不便 を与えないような, 生活適合性が要求される. また, 安全 安心な社会の実現として, 人のモニタリングや医療用途の センサ・デバイス開発が重要である.

このようなセンサ・デバイスの実現のためには，その電 源技術の開発が重要であるが, 現状の機器開発においては, その重要性の認識は必ずしも高くない. 現行のIoT セン サ用の電源としては, ボタン型一次電池やキャパシタなど の市販電池と無線給電の組み合わせが検討されている. し かしながら, 電源としての持ち時間が短いので, 絶えず無 線給電する必要がある。 その結果, IoT やウェアラブルセ ンサに用いる際には, 絶えず無線給電できる使用距離や使 用環境が必要であるため, サービス・流通分野への応用に は大きな制限があった。 また，ロボット技術においても， 電源技術は既存技術の流用で考えている場合が多く, 口 ボットが重くて大きな鉛蓄電池のリュックを背負ったケー スも見られることから問題であった.

このような状況で，我々は，七ンサ・デバイスに実装す るための技術, 機器と一体化した本格的な電源技術, 実使 用環境に適合した耐久性・安全性, センサ寿命と同程度の 長時間使用可能な電源技術の開発が必要不可欠と考えてい る. 本稿では, IoT センサ・デバイスに適する電源技術と して, 産業技術総合研究所 (以下, 産総研) で取り組んで いる全固体電池技術について紹介する。

\section{IoT センサ・デバイスに適した電源技術}

今日, 市販されている二次電池の中で, 最も一般的なも のはリチウムイオン電池である. 歴史的には, 1990 年代

Solid-State Battery Technologies for Advanced IoT Sensor Device Applications

* Akimoto, Junji/Nagata, Hiroshi/Kataoka, Kunimitsu/

Akao, Tadayoshi/Akedo, Jun

産業技術総合研究所 先進コーティング技術研究センター

つくば市東 1-1-1（テ 305-8565）

j.akimoto@aist.go.jp

2019.5. 6 受理
岡 邦 光* ·赤尾 忠 義* ·明 渡 純*

に, ポータブル電子機器用の電源として実用化され, その 後，ノートパソコンや携带電話，スマートフォンの普及を 支えてきた重要な電源技術である。また，今後は，自動車 用途などの大型電源技術としても普及・展開が期待されて いる.

現行のリチウムイオン電池は，正極材料と負極材料の間 を, 電解液を経由してリチウムイオンが出入りすることに よって充放電が可能となる化学電池の一種である。 スマー トフォン用の電池では, 正極材料活物質としてリチウムコ バルト酸化物が, 負極材料活物質としては, グラファイト などの炭素系材料が, 電解液としては無機のリチウム塩を 有機系電解液に溶解させたものが用いられている．電池の 構成の概念図を図 1 に示す. 充電反応によって, リチウム コバルト酸化物の結晶構造から, 層間のリチウムイオンの 約半分が抜け出し, 負極活物質であるグラファイトの層間 に入る．放電反応では，逆にグラファイトの層間にいたリ チウムイオンが，元のリチウムコバルト酸化物の層間に戻 る.このリチウムイオンが出入りする反応は，1000 回以 上繰り返しても, 結晶構造が崩れることなく可逆的に起こ ることから, ニッケルカドミウム電池やニッケル水素電池 などの他の二次電池と比べて, 高電位・高容量 - 長寿命の 二次電池であることが特徵である.

IoT センサ・デバイス用途の電源技術として, 充放電可 能な二次電池の中で, 高容量と高電圧が可能となるこのよ うなリチウムイオン電池の使用が期待されている. しかし ながら, 例えば電池の動作環境や動作温度を考えると, 現 行のリチウムイオン電池の技術では，有機系の電解液を使 用していることから， $60{ }^{\circ} \mathrm{C}$ 以上の高温作動は不可能であ

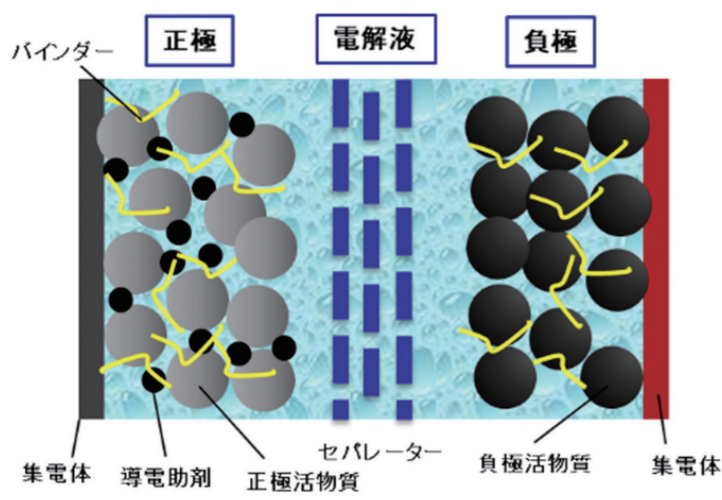

図 1 現行のリチウムイオン電池の構成の概念図 
る.また，電池からの液漏れの心配があるため，デバイス に実装することも困難と思われる．さらに現行の小型電子 機器用のリチウムイオン電池は, 電池の寿命も 3 年程度と 短く，そのまま市販電池を使用した場合には電池交換が必 要となることから, IoT 用途に応用する際の大きな課題で あった。

ウェアラブル機器の開発, 高温環境下でも動作可能な IoT デバイスのために，目指すべき電源技術のスペックと しては，1）デバイスの使用期間に抏いて電池交換不要で あること，2）チップコンデンサのように小型かつ大容量 であること，3）他の電子部品と一緒に集積実装可能であ ること，4）無線給電により非接触で充電可能なこと，な どが挙げられる．さらに，はんだリフロー温度 $\left(250{ }^{\circ} \mathrm{C}\right)$ に耐え，耐環境性にも優れたパッケージング技術の開発も 必要と考えられる．このような技術を社会実装することで, これまで別々に開発されていたデバイスと電源技術が，ア プリケーションに特化した形での電源を実装したデバイス 機器となることで, 新しいビジネスモデルの創出が期待さ れる。

このような新規な高容量・超小型の電源技術として, 可 燃性の有機系電解液を無機系の固体電解質に代替した，全 固体電池の開発が最適と考えられる。電解質を固体とする ことで, 現行リチウムイオン電池で問題となっていた，電 解液由来の副反応が起こらないため, 原理的には, 寿命特 性の大幅な改善も期待できるというメリットもある。また, 部材がすべて固体であるため, 電極の積層構造化が容易で あり，また，電池の形状がフレキシブルになる，などの効 果も期待される。このようなメリットが多い全固体電池で はあるが，一部，薄膜電池としては実用化されたものの， 現在までに全固体電池は実現できていなかった。その原因 は, 電解質材料自体のリチウム伝導特性が悪かった点, お よびリチウムイオンが伝導できる電極材料と電解質材料の 界面の構築技術, 電池の製造プロセスや電池システムが確 立していないことが挙げられる.

\section{3 . 全固体電池開発と現状の課題}

現在, 可燃性の有機電解液に替わり, 固体電解質を用い た全固体リチウム二次電池の開発が国内外で進められてい る. 図 2 に全固体電池の構成の概念図を示す. 固体電解質 材料としては，無機固体電解質材料と有機ポリマー材料が 広く知られており，特に無機固体電解質材料は不燃性であ るため，発火することがない高安全性を特徽とした全固体 リチウム二次電池の実現に向けて開発が行われている. 現 在, 有力な無機固体電解質材料として, 硫化物と酸化物の 二種類がある. 硫化物固体電解質材料は酸化物固体電解質 材料よりも一桁以上リチウムイオン伝導性が良好であり， 可塑性に優れた固体であるため電極と固体電解質の界面の 接合が容易に形成できる，というメリットがあることから，

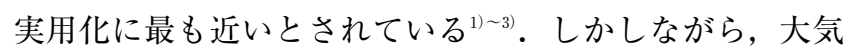
中に暴露すると有毒な硫化水素ガスを発生するため, 実際 の使用には堅牢な封止技術が必要であり，また，安全性の 観点からも, ウェアラブルデバイスへの電池実装は困難と 思われる.これに対して, 酸化物固体電解質材料は, 化学 的な安定性が高く, 環境適合性の点で優れるが, 従来技術

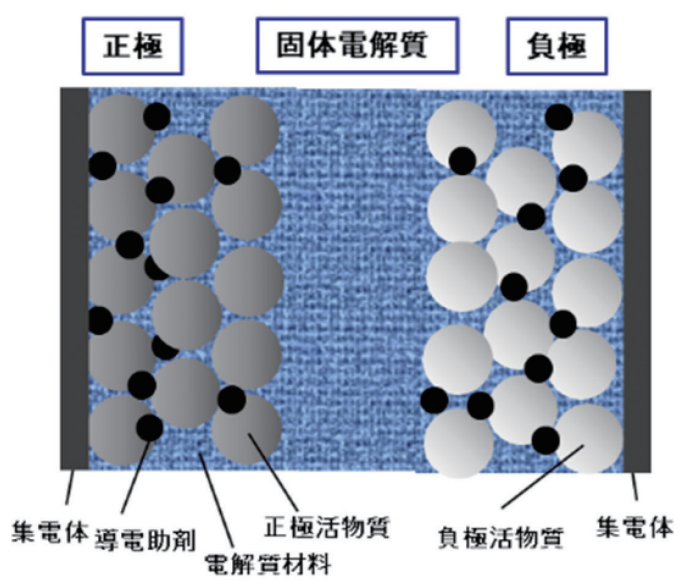

园 2 全固体電池の構成の概念図

では，リチウムイオン伝導性が有機電解液より低いこと， 硫化物系固体電解質材料のような可塑性にそしいため, 圧 粉体での界面の接合が困難なことなどが課題としてあった. セラミックスの界面を接合する技術として, 通常は, 高温 での熱処理が一般的であるが, リチウムイオン電池の電極 材料と電解質材料が反応することで, 絶縁層としての界面 反応層が形成されてしまう場合が多く, 界面の接合に課題 があった。

さらに，焼結体を用いた電解質部材の検討の結果，相対 密度が $95 \%$ を超えるような緻密な焼結体であっても, 室 温条件下では $1 \mathrm{~mA} / \mathrm{cm}^{2}$ 以下の電流密度で内部短絡して しまう現象が多くの研究者によって報告されている(1). 内部短絡は，負極あるいは負極表面に析出した金属りチウ ムが, 電解質部材の中をデンドライト成長することで貫通 することにより，正極と負極が金属で短絡してしまう現象 である. 現行の液系リチウムイオン電池でも問題であった が，全固体電池とすることでは解決できないことが明らか となっている. 有機電解液のように発煙, 発火には至らな いが，電源技術としての安定性・信頼性の観点では問題で あった．内部短絡する現象のメカニズムについても多くの 取り組みがなされ，1）電解質材料の機械的性質〉，2）界 面の平滑性 ${ }^{6}$, 3) 電解質材料の電子伝導性 ${ }^{8}$, などが原因 とされている. 現象としては, 図 3 に示すように, 多結晶 体であるセラミックスの粒界に沿って金属リチウムがデン ドライト成長していることが確認されていることから, 電

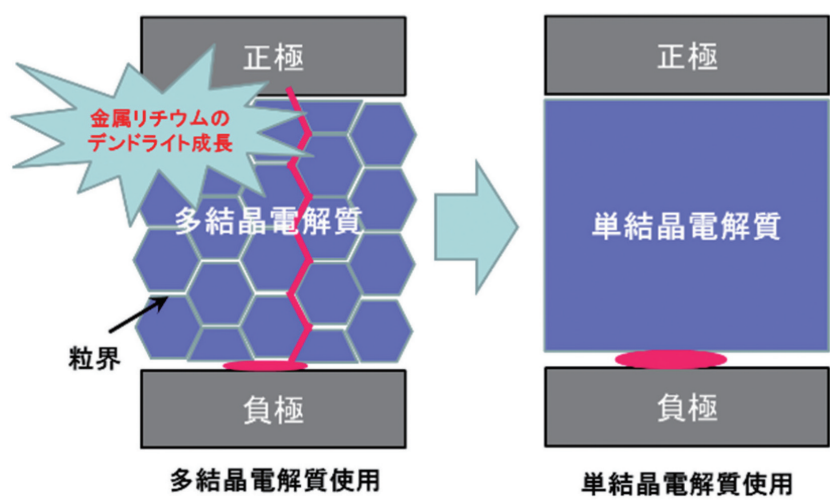

図 3 単結晶電解質部材の使用による内部短絡抑止技術の 概念図 
解質部材として粒界をなくす，すなわち単結晶を電解質部 材とすることが内部短絡を起こさないための近道と考えら れたが，これまでの単結晶育成の報告がなかった．IoT セ ンサの電源の仕様を想定すると, 無線送信する際に, 瞬間 的な大電流が必要となることから，内部短絡を抑制できる 電解質部材の開発が必要であった。

電池を実装したIoT デバイスに㧍いては，キーとなる 電源技術として，1）ハンダのリフローが可能なこと，2） 無線給電が可能なこと, 3) 電池の容量・寿命が機器の寿 命を短くしないこと, が求められる。これらの仕様を満た す電池は, 酸化物系の全固体型リチウム二次電池しかなく, 固体電池の開発が必要である. しかしながら, 安全性・信 頼性の観点で期待されている酸化物型固体電池は, 現状で は研究途上の電池技術であり, 微小容量の薄膜電池以外は 実用化には至っていない。

\section{4. 単結晶電解質部材の開発}

このような状況で, 産総研では, 全固体電池開発のキー となる固体電解質材料に注力して研究開発を進めてきた. 特に, 酸化物電解質材料の中で, 1) 比較的リチウムイオ ン伝導性が良好なこと，2）金属リチウムに対する耐還元 性を有すること, の観点から, 図 4 に示すガーネット型材 料 $\mathrm{Li}_{7} \mathrm{La}_{3} \mathrm{Zr}_{2} \mathrm{O}_{12}$ (LLZ) にフォーカスした材料研究を展開 してきだ) 14). また，金属りチウムのデンドライト成長を 抑制するための技術として, 粒界のないセラミックスであ るバルク単結晶部材の開発に成功した (図 5$)^{15)}$, 16). 作製さ れた単結晶を用いて作製された固体電解質部材は, 短絡試

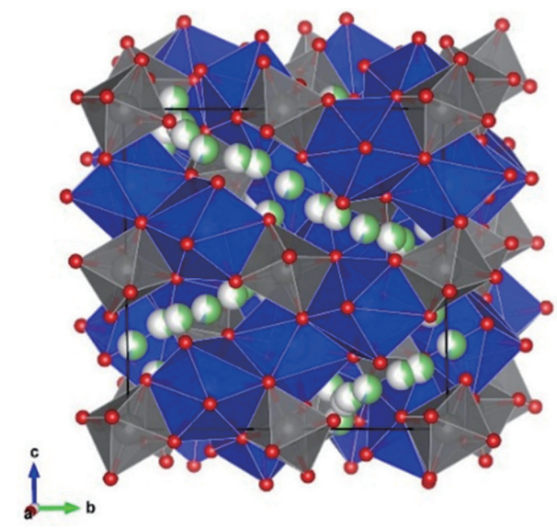

図 4 ガーネット型固体電解質材料 LLZ の結晶構造
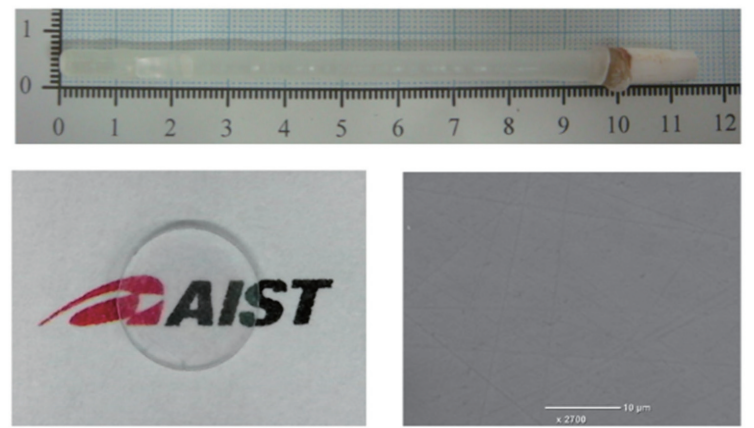

図 5 大型 LLZ 単結晶の育成と成形加エした単結晶電解 質部材

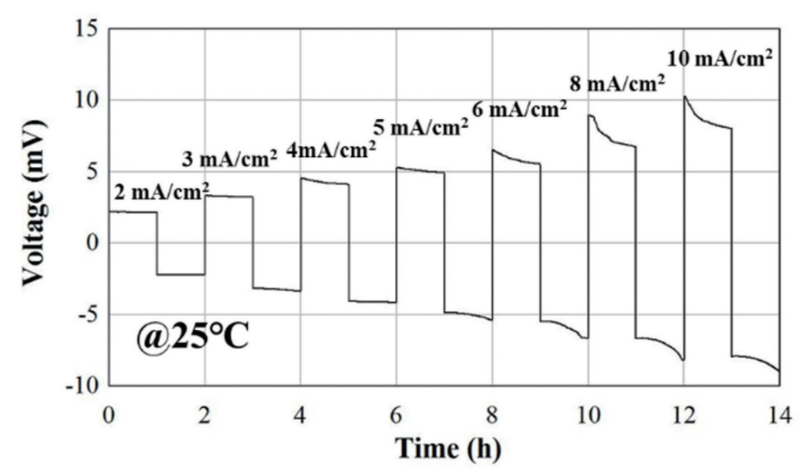

図 6 直流分極測定による単結晶電解質部材の内部短絡試験

験の結果， $10 \mathrm{~mA} / \mathrm{cm}^{2}$ の大電流でも内部短絡せず，信頼 性が高いことがわかった（図 6)。また， $25^{\circ} \mathrm{C} て ゙ ~ 10^{-3} \mathrm{~S} / \mathrm{cm}$ を超えるバルクのリチウムイオン伝導性を電解質部材とし て達成できることを明らかにした しては現行の有機系電解液とほほ同等のリチウムイオン伝 導性である。

今回，単結晶製造に適用した育成手法は，半導体結晶や 光学結晶の育成技術としてよく知られている融液からの結 晶成長技術である。従って, 単結晶の大型化, 工業化が可 能な製造技術と考えている。

\section{5. エアロゾルデポジション法（AD 法）による 全固体電池作製}

さらに, 電極と固体電解質の界面の接合手法として, 産 総研独自のコーティング技術であるエアロゾルデポジショ ン（AD）法を応用した。この方法は，常温衝撃固化現象 (Room Temperature Impact Consolidation : RTIC) の発 見をべースとして，従来のセラミックスのコーティング技 術のような加熱を必要とせず，常温で強固なセラミックス のコーティングが可能となる ${ }^{18,19}$. $\mathrm{AD}$ 法は, 図 7 に示す ように, 微粒子を空気などのガスと混合し, 減圧下でノズ ルから噴射することで，エアロゾルジェットとして基板に 衝突させ，膜を形成する技術であり，緻密で密着強度が高 いセラミックス膜を，金属，ガラス，プラスチックなどさ まざまな材質の基板上に常温で形成できる成膜プロセスで ある。このような $\mathrm{AD}$ 法の特徴である常温で成膜をでき る点, 密着強度の高い成膜をできる点が, 全固体電池の電 極形成に適していることが知られている，具体的には，前 述のガーネット型酸化物単結晶を加工・成形した固体電解 質部材を基材として，正極材料を $\mathrm{AD}$ 法により成膜し， 密着性が高い電極一電解質界面を形成することができた。

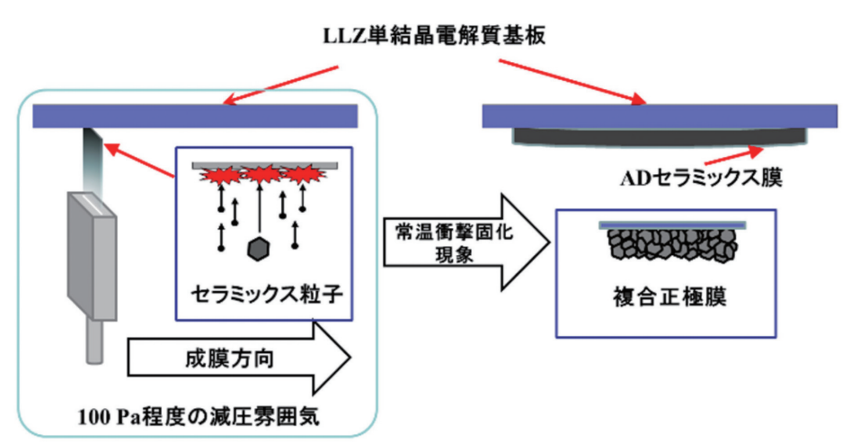

図 $7 \quad \mathrm{AD}$ 法による電極成膜の概念図 


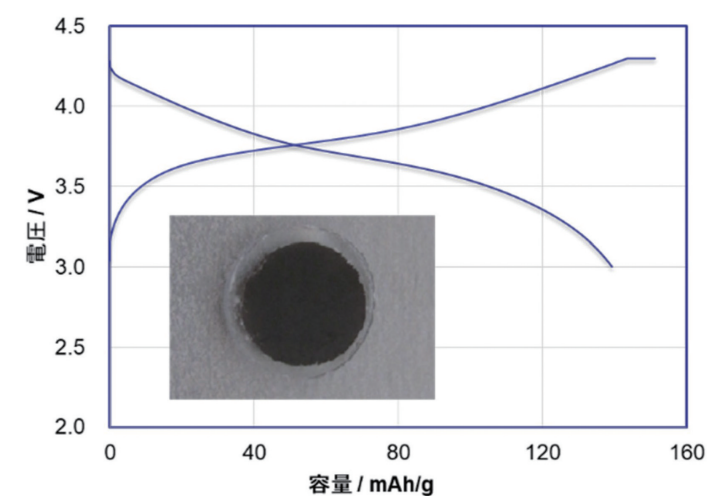

図 8 AD 法による成膜された複合正極と全固体電池の 電池特性

また，正極内のリチウムイオン伝導性を確保するために， 正極材料と電解質材料の複合電極の成膜にも成功している. 図 8 に単結晶基板上に複合正極を成膜した状態の写真を 示す.

成膜した基板の反対側に負極材料である金属リチウムを 圧着することで，全固体電池を作製し，電池特性の評価を 行った ${ }^{20,21)}$. その結果, 図 8 に示すように $60{ }^{\circ} \mathrm{C} の$ 高温動 作で, 安定した充放電が可能であることが明らかとなった. 現状では，電極の導電率が低いため，微弱な微小電流での 充放電動作しかできておらず, 更なる電極構造の最適化を 図っている.

一方, 今回の電池構成では, 試作した全固体電池は, 外 装の材料を選択することで，原理的に $200{ }^{\circ} \mathrm{C}$ 以上の高温 にも耐える耐熱性を有するものである.これらの固体電池 技術をべースとすることで，デバイス実装の固体電池への 展開を検討している。

\section{6.おわりに}

IoT センサ・デバイスに実装する電源技術として，産総 研で取り組んでいる全固体電池の研究開発について紹介し たまた，電源技術として実用化するためには，多くのブ レークスルーとなる技術の開拓が必要であり，ひとつひと つの課題を地道に克服していく努力が必要である. IoTセ ンサ・デバイスの展開に伴って，必要となる電源のスペッ クも多種多様となることが予想される，従って，電源技術 を実装したIoT センサ・デバイスの開発が求められてい る. 全固体電池による電源技術によって，社会実装に繋が るウェアラブルデバイス, 或いはフレキシブルデバイスの 安定性・信頼性の飛躍的な向上に資すると考えている.

\section{参 考 文 献}

1 ) Hayashi, A., Minami, K., Ujiie, S. and Tatsumisago, M. : J. Non-Cryst. Solids, 356, 2670 (2010)
2) Kamaya, N., Homma, K., Yamakawa, Y., Hirayama, M., Kanno, R., Yonemura, M., Kamiyama, T., Kato, Y., Hama, S., Kawamoto, K. and Mitsui, A. : Nature Mater., 10, $682(2011)$

3 ) Kato, Y., Hori, S., Suzuki, K., Hirayama, M., Mitsui, A., Yonemura, M., Iba, H. and Kanno, R. : Nature Energy, 1, 16030 (2016)

4 ) Sudo, R., Nakata, Y., Ishiguro, K., Matsui, M., Hirano, A., Takeda, Y., Yamamoto, O. and Imanishi, N. : Solid State Ionics, 262, 151 (2014)

5 ) Takeda, Y., Yamamoto, O. and Imanishi, N. : Electrochemistry, 84, 210 (2016)

6 ) Sharafi, A., Meyer, H. M., Nanda, J., Wolfenstine, J. and Sakamoto, J. : J. Power Sources, 302, 135 (2016)

7 ) Porz, L., Brian, T. S., Sheldon, W., Rettenwander, D., Frömling. T., Thaman, H. L., S. Berendts, S., Uecker, R., Carter, W. C. and Chiang, Y. M. : Adv. Energy Mater., 7, 1701003 (2017)

8 ) Han, F., Westover, A. S., Yue, J., Fan, X., Wang, F., Chi, M., Leonard, D. N., Dudney, N. J., Wang, H. and Wang, C. : Nature Energy, 4, 187 (2019)

9 ) Murugan, R., Thangadurai, V. and Weppner, W. : Angew. Chem., Int. Ed., 46, 7778 (2007)

10) Awaka J., Kijima, N., Hayakawa, H. and Akimoto, J. : J. Solid State Chem., 182, 2046 (2009)

11) Awaka, J., Takashima, A., Kataoka, K., Kijima, N., Idemoto, Y. and Akimoto, J. : Chem. Lett., 40, 60 (2011)

12) Hamao, N., Kataoka, K., Kijima, N. and Akimoto, J. : J. Ceram. Soc. Jpn., 124, 678(2016)

13) Hamao, N., Kataoka, K. and Akimoto, J. : J. Ceram. Soc. Jpn., 125, 272 (2017)

14）浜尾尚樹，片岡邦光，秋本順二：日本セラミックス協 会誌，53，260(2018)

15) Kataoka, K. and Akimoto, J. : ChemElectroChem, 5, 2551 (2018)

16) Kataoka, K., Nagata, H. and Akimoto, J. : Scientific Reports, 8, 9965 (2018)

17）片岡邦光, 永田裕, 秋本順二：日本結晶成長学会誌, 46, 46-1-02(2019)

18) Akedo, J. : J. Am. Ceram. Soc., 89, 1834 (2006)

19) 明渡純：エロゾルデポジション法の新展開－常温衝撃 固化現象活用の最前線－，シーエムシー出版 (2019)

20）片岡邦光，赤尾忠義，永田裕，永井秀明，秋本順二， 明渡純：シンセシオロジー，12，28(2019)

21）片岡邦光, 赤尾忠義, 永井秀明, 秋本順二, 明渡純： 自動車技術，72，38(2018) 